\title{
UJI MUTU TEPUNG BIJI NANGKA (Artocarpus heterophyllus Lamk) DENGAN TEKNIK PEMBUATAN METODE KERINGDAN METODE BASAH
}

\author{
Erna Agung Rakhmawati ${ }^{1}$, Siti Musdholifah ${ }^{2}$ \\ ${ }^{1,2)}$ Akafarma Sunan Giri Ponorogo, J1. Batoro Katong 32 Ponorogo \\ e-mail: ${ }^{1)}$ erna.akafarma@gmail.com
}

\begin{abstract}
Abstrak
Latar belakang: Nangka (Artocarpus heterophyllus L) adalah salah satu jenis buah yang banyak ditanam didaerah tropis seperti Indonesia. Selama ini, bagian buah nangka yang umun dikonsumsi adalah nangka muda, nangka masak, dan bijinya. Biji nangka dapat diolah dalam bentuk tepung dan dimanfaatkan sebagai bahan pengganti sebagai sumber karbohidrat, karena dalam biji nangka terdapat karbohidrat sebanyak 36,7 gram per 100 gram. Tujuan: bertujuan untuk pembuatan tepung biji nangka dengan metode kering dan metode basah dilakukan uji untuk mengetahui organoleptik, kadar air, kadar abu dan cemaran mikroba berdasarkan Standar Nasional Indonesia No. 3751 tahun 2009.Metode: metode yang digunakan dalam penelitian ini, yaitu kadar air dengan metode gravimetric, kadar abu dengan metode pengabuan kering (secara langsung), uji cemaran mikroba dengan metode ALT dan metode AKK. Sampel yang digunakan dalam penelitian ini sebanyak 300 gram dan untuk kadar air dan kadar abu dilakukan pengulangan sebanyak tiga kali. Hasil: Dari hasil pengujian mutu dapat dinyatakan bahwa tepung biji nangka memenuhi persyaratan mutu dari Standar Nasional Indonesia No. 3751 tahun 2009 kecuali kadar abu. Produk tepung biji nangka pada metode kering memiliki hasil uji organoleptik bentuk serbuk, bau khas tepung, warna putih kecoklatan, kadar air 7,5\%, kadar abu 1,11\%, ALT 15,5 × 103 koloni/gram, AKK $70 \times 10^{2}$ koloni/gram. Merode basah memiliki hasil uji organoleptik bentuk serbuk, bau khas tepung, warna putih kekuningan, kadar air 8,4\%, kadar abu 1,45\%, ALT $19 \times 10^{1}$ koloni/gram, AKK 34 $\times 10^{3} \mathrm{koloni} / g r a m$. Simpulan dan saran: hasil Uji tepung nangka sebagian besar memenuhi persyaratan, kecuali pada kadar aby. Karena melebihi persyaratan. Diharapkan dapat dilakukan uji mutu lainnya.
\end{abstract}

Kata Kunci : tepung biji nangka, organoleptik, kadar air, kadar abu, ALT, AKK

\begin{abstract}
Background: Jackfruit (Artocarpus heterophyllus L) is one type of fruit that is widely grown in tropical regions such as Indonesia. During this time, the common portion of jackfruit consumed is young jackfruit, cooked jackfruit, and seeds. Jackfruit seeds can be processed in the form of flour and used as a substitute as a source of carbohydrates, because there are 36.7 grams of carbohydrates per 100 grams of jackfruit seeds. Objectives: This study aims to produce jackfruit seed flour with a dry method and a wet method tested for knowing organoleptic, water content, ash content and microbial contamination based on Indonesian National Standard No. 3751 in 2009.Methods: Some of the methods used in this study, namely the water content with the gravimetric method, ash content with the dry ashing method (directly), microbial contamination test using ALT method and AKK method. The sample used in this study was 300 grams and repetition of water content and ash content three times.Results: From the results of quality testing it can be stated that jackfruit seed flour meets the quality requirements of Indonesian National Standard No. 3751 in 2009 except ash content. The product of jackfruit seed flour in the dry method has powdered organoleptic test results, typical flour odor, brownish white, water content 7,5\%, ash content $1.11 \%$, ALT $15.5 \times 10^{3}$ colonies / gram, AKK $70 \times 10^{2}$ colonies / gram. Wet merode has powdered organoleptic test results, typical flour smell, yellowish white color, moisture content $8,4 \%$, ash content $1.45 \%$, ALT $19 \times 10^{1}$ colonies / gram, AKK $34 \times 10^{3}$ colonies / gram. Conclusions and suggestions: Jackfruit flour test results mostly meet the requirements, except for aby content. Because it exceeds the requirements. Another quality test is expected to be carried out..
\end{abstract}


Keywords : jackfruit seed flour, organoleptic, water content, ash content, ALT,AKK

\section{PENDAHULUAN}

Nangka (Artocarpus heterophyllus Lamk ) adalah salah satu jenis buah yang banyak ditanam di daerah tropis seperti Indonesia. Tanaman ini cukup dikenal seluruh dunia. Buah nangka memiliki beragam manfaat untuk kesehatan, diantaranya: memperkuat sistem kekebalan tubuh karena mengandung vitamin $\mathrm{C}$ yang merupakan antioksidan yang sangat baik, kaya akan kalium untuk mengontrol tekanan darah dan bisa mengurangi resiko terkena penyakit jantung, stroke, dan juga baik untuk menjaga keseimbangan elektrolit, mengandung fitonutrien seperti lignan, isoflavon, dan saponin yang membentuk proteksi tubuh melawan timbunya sel kanker, kandungan vitamin A dan antioksidan yang tinggi baik untuk menjaga dan memelihara kesehatan kulit, dan mengandung mineral seperti mangan, zat besi, vitamin B6, niasin, asam folat yang berfungsi untuk megoptimalkan fungsi tubuh. Biji nangka merupakan sumber karbohidrat (36,7 g/100 g), protein (4,2 g/100 g), dan energi (165 kkal/100 g) yang cukup tinggi sehingga dapat dimanfaatkan sebagai bahan pangan yang potensial. (Astawan,2007).

Menurut Kamus Besar Bahasa Indonesia (KBBI) tepung merupakan bahan yang digiling sehingga menjadi serbuk atau bubukan.Tepung adalah partikel padat yang berbentuk butiran halus atau sangat halus tergantung pemakaiannya. Biasanya digunakan untuk keperluan penelitian, rumah tangga, dan bahan baku industri. Tepung bisa berasal dari bahan nabati misalnya tepung terigu dari gandum, tapioka dari singkong, maizena dari jagung atau hewani misalnya tepung tulang dan tepung ikan.Tepung merupakan bahan pangan yang banyak mengandung karbohidrat dan juga dapat dijadikan sebagai komoditi pengganti beras (Ikhsanudin,2010).Tepung merupakan salah satu bahan yang digunakan dalam pembuatan berbagai olahan makanan.Tepung memiliki keunggulan yaitu tahan disimpan, mudah dicampur, ditambah zat gizi, dibentuk, dan lebih cepat dimasak sesuai dengan kehidupan modern yang serba praktis (Winarno,2000).

Menurut Farmakope Indonesia kadar air adalah banyaknya hidrat yang terkandung dalam bahan yang dinyatakan dalam persen. Abu merupakan residu anorganik dari proses pembakaran atau oksidasi kelompok organik bahan pangan. Angka lempeng total adalah jumlah bakteri mesofil dan tiap 1 (satu) ml atau 1 (satu) gram sampel yang dianalisis. Angka kapang khamir merupakan metode yang digunakan untuk menetapkan angka kapang atau khamir dalam makanan dan minuman (BPOM, 2006).

\section{METODE PENELITIAN}

Pada Penelitian ini digunakan metode Uji Kualitatif dan Uji Kuantitaif. Berupa Uji Organoleptik, uji kadar air, uji kadar abu, uji ALT dan uji AKK. Teknik yang digunakan untuk mengambil sampel adalah Random sampling. 
1. Pembuatan tepung biji nangka

Pemilihan biji nangka, kemudian pensortiran. Timbang biji nangka sebanyak $2 \mathrm{~kg}$, kemudian dilakukan pengupasan, pencucian dan perajangan. Keringkan dibawah sinar matahari langsung selama \pm 3 hari atau sampai kering. Blender biji nangka dan ayak menggunakan ayakan stainless stel 80 mesh.

2. Uji mutu tepung biji nangka

a. Organoleptik. Amati tekstur, bau dan warna

b. Uji kadar air. Panaskan porselen dengan oven pada suhu $150^{\circ} \mathrm{C}$ selama 15 menit. Dinginkan pada desikator. Timbang bobot porselen. Dimasukkan 2 g sampel pada kurs porselen. Keringkan pada oven suhu $150^{\circ} \mathrm{C}$ selama 1 jam. Dinginkan pada desikator. Timbang

c. Uji Kadar Abu. Pijarkan cawan pada tanur suhu $550^{\circ} \mathrm{C}$. Dinginkan pada desikator dan timbang tanur. Masukkan $5 \mathrm{~g}$ sampel dalam cawan tersebut, tanur suhu $550^{\circ} \mathrm{C}$ sampai putih kelabu atau selama 5 sampai 8 jam. Dinginkan pada desikator lalu timbang. Masukkan kembali pada tanur selama 1 jam dengan suhu sama. Dinginkan pada desikator lalu timbang. Hitung bobot konstan.

d. Uji ALT. Timbang $25 \mathrm{~g}$ sampel, masukkan erlenmeyer ditambah $225 \mathrm{ml}$ pepton 0,1\%. Kocok dan beri etiket $10^{1}$. Ambil $1 \mathrm{ml}$ pada pengenceran $10^{1}$ lalu masukkan tabung kedua, ditambah pepton $9 \mathrm{ml}$. Beri etiket $10^{2}$. Lakukan hingga diperoleh pengenceran $10^{3}$. Dari setiap pengenceran, pipet $1 \mathrm{ml}$ masukkan cawan petri lalu ditambah $10 \mathrm{ml}$ media NA. Ratakan. Inkubasi pada suhu $35-37{ }^{\circ} \mathrm{C}$ selama $24-48$ jam dengan posisi dibalik.

e. Uji AKK. Buat pengenceran sebanyak $10^{3}$. Masing-masing pengenceran dipipet $0,5 \mathrm{ml}$, dituangkan pada permukaan media SGA+kloramfenikol, putar hingga suspensi tersebar merata. g. Seluruh cawan petri inkubasi pada suhu $20-25^{\circ} \mathrm{C}$ dan amati pada hari ke- 3 sampai hari ke-5.

\section{HASIL DAN PEMBAHASAN}

Sampel tepung biji nangka dilakukan Uji Kualitatif dan Uji Kuantitaif. Berupa Uji Organoleptik, uji kadar air, uji kadar abu, uji ALT dan uji AKK. Dengan hasil sebagai berikut :

1. Hasil Uji Organoleptik

Tabel 1. Hasil Uji Organoleptik

\begin{tabular}{cccc}
\hline \multirow{2}{*}{ Sampel Produksi } & \multicolumn{2}{c}{ Hasil Uji Organoleptik } \\
\cline { 2 - 4 } & Bentuk & Bau & Warna \\
\hline $\begin{array}{c}\text { Tepung biji nangka } \\
\text { dengan metode kering }\end{array}$ & Serbuk & $\begin{array}{c}\text { Khas } \\
\text { tepung }\end{array}$ & $\begin{array}{c}\text { Putih } \\
\text { kecoklatan }\end{array}$ \\
\hline $\begin{array}{c}\text { Tepung biji nangka } \\
\text { dengan metode basah }\end{array}$ & Serbuk & $\begin{array}{c}\text { Khas } \\
\text { tepung }\end{array}$ & $\begin{array}{c}\text { Putih } \\
\text { kekuningan }\end{array}$ \\
\hline
\end{tabular}

2. Hasil Uji Kadar Air Persyaratan Maksimum 14,5\%

Tabel 2. Hasil Uji Kadar Air

\begin{tabular}{|c|c|c|}
\hline Sampel & Pengulangan & Kadar air (\%) \\
\hline Tepung & K1 & 7,3 \\
\hline nangka & K2 & 7,5 \\
\hline metode kering & K3 & 7,6 \\
\hline Tepung & B1 & 8,4 \\
\hline nangka & B2 & 8,4 \\
\hline metode basah & B3 & 8,5 \\
\hline
\end{tabular}


Vol. 1, No.2, Desember 2019, hal55-60

3. Hasil Uji Kadar Abu Persyaratan Maksimum 0,7\%

Tabel 3. Hasil Uji Kadar Abu

\begin{tabular}{|c|c|c|}
\hline Sampel & Pengulangan & Kadar abu (\%) \\
\hline Tepung & K1 & 3,40 \\
\hline nangka & $\mathrm{K} 2$ & 1,19 \\
\hline metode kering & K3 & 1,03 \\
\hline Tepung & B1 & 1,36 \\
\hline nangka & B2 & 1,54 \\
\hline metode basah & B3 & 2,98 \\
\hline
\end{tabular}

4. Hasil Uji Angka Lempeng Total Persyaratan Maksimum $1 \times 10^{6}$

Tabel 4. Hasil Uji ALT

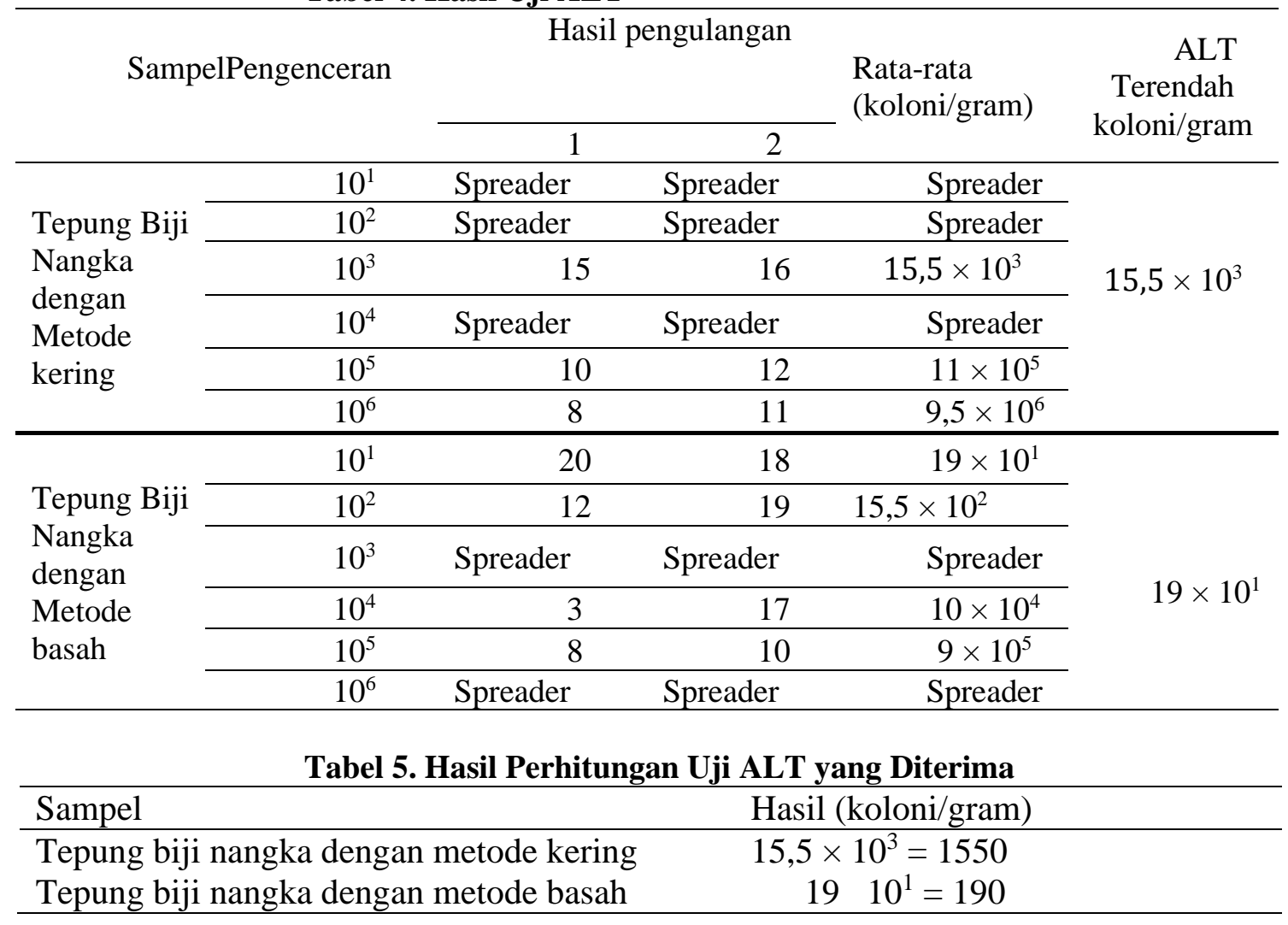


5. Hasil Uji Angka Kapang Khamir (AKK) Persyaratan Maksimum $1 \times 10^{4}$ koloni/gram

Tabel 6. Hasil Uji AKK

\begin{tabular}{|c|c|c|c|c|c|}
\hline \multirow{2}{*}{ Sampel } & \multirow{2}{*}{ Pengenceran } & \multicolumn{2}{|c|}{ Hasil pengulangan } & \multirow{2}{*}{$\begin{array}{l}\text { Rata-rata } \\
\text { (koloni/gram) }\end{array}$} & \multirow{2}{*}{$\begin{array}{l}\text { AKK terendah } \\
\text { koloni/gram }\end{array}$} \\
\hline & & 1 & 2 & & \\
\hline \multirow{4}{*}{$\begin{array}{l}\text { Tepung Biji } \\
\text { Nangka } \\
\text { dengan } \\
\text { Metode } \\
\text { kering } \\
\end{array}$} & $10^{1}$ & Spreader & Spreader & Spreader & \multirow{4}{*}{$70 \times 10^{2}$} \\
\hline & $10^{2}$ & 90 & 50 & $70 \times 10^{2}$ & \\
\hline & $10^{3}$ & 135 & 145 & $140 \times 10^{3}$ & \\
\hline & $10^{4}$ & 100 & 110 & $105 \times 10^{4}$ & \\
\hline \multirow{4}{*}{$\begin{array}{l}\text { Tepung Biji } \\
\text { Nangka } \\
\text { dengan } \\
\text { Metode } \\
\text { basah }\end{array}$} & $10^{1}$ & Spreader & 20 & $20 \times 10^{1}$ & \multirow{4}{*}{$34 \times 10^{3}$} \\
\hline & $10^{2}$ & 30 & 35 & $27,5 \times 10^{2}$ & \\
\hline & $10^{3}$ & 40 & 28 & $34 \times 10^{3}$ & \\
\hline & $10^{4}$ & 90 & 80 & $85 \times 10^{4}$ & \\
\hline
\end{tabular}

Tabel 7. Hasil Uji AKK yang Diterima

\begin{tabular}{cc}
\hline Sampel & Hasil (koloni/gram) \\
\hline Tepung biji nangka dengan metode kering & $70 \times 10^{2}=7000$ \\
Tepung biji nangka dengan metode basah & $34 \times 10^{3}=34000$ \\
\hline
\end{tabular}

Uji organoleptik tepung biji nangka dari metode kering diperoleh hasil pengamatan bentuk serbuk dengan bau khas tepung dan warna putih kecoklatan dan metode basah diperoleh hasil pengamatan bentuk serbuk dengan bau khas tepung dan warna putih kekuningan.Perbedaan pada warna disebabkan oleh faktor pengolahan karena metode yang digunakan berbeda dan satu sampel dalam pengolahannya direndam menggunakan air kapur.Kadar air tepung biji nangka memenuhi persyaratan mutu tepung terigu SNI 3751:2009 karena kadar air yang diperoleh kurang dari 14,5\%. Produksi tebung biji nangka dengan metode kering diperoleh kadar air sebesar 7,5\%dan produksi dengan metode basah diperoleh kadar air sebeasr $8,4 \%$.Kadar abu pada produk tepung biji nangka dengan metode kering dan metode basah tidak memenuhi persyaratan mutu tepung terigu SNI 3751:2009, karena kadar abu yang diperoleh melebihi dari kadar maksimum yang telah ditentukan yaitu 0,70\%. Diperoleh kadar abu pada produksi tepung biji nangka dengan metode kering sebesar $1.11 \%$ dan produksi dengan metode basah sebesar 1,45\%. ALT pada tepung biji nangka dari metode kering dan metode basah memenuhi persyaratan mutu tepung terigu SNI 3751:2009, karena dari dua sampel menunjukan hasil yang masih ditoleransi dari batas maksimum yaitu $1 \times 10^{6} \mathrm{koloni} /$ gram. AKK pada tepung biji nangka pada metode kering dan metode basah memenuhi persyaratan mutu tepung terigu SNI 3751:2009, karena dari dua sampel menunjukan hasil yang masih ditoleransi dari batas maksimum yaitu $1 \times 10^{4}$ koloni/gram 


\section{SIMPULAN}

Berdasarkan hasil penelitian dapat disimpulkan bahwa:

1. Hasil uji organoleptik tepung biji nangka dengan metode kering dengan bentuk serbuk, bau khas tepung, dan warna putih kecoklatan. Kadar air tepung biji nangka dengan metode kering sebesar 7,5\% yang masih dalam batas toleransi persyaratan SNI 3751:2009 sebesar 14,5\%. Untuk kadar abu dengan metode kering sebesar 1,11\% tidak memenuhi persyaratan SNI 3751:2009 sebesar 0,70\%. Untuk uji ALT dengan metode kering diperoleh 15,5 × 103 koloni/gram. Uji AKK dengan metode kering diperoleh $70 \times 10^{2} \mathrm{koloni} /$ gram yang masih dalam batas toleransi persyaratan SNI 3751:2009 untuk ALT sebesar $1 \times 10^{6}$ dan AKK sebesar $1 \times 10^{4}$.

2. Hasil uji organoleptik tepung biji nangka dengan metode basah dengan bentuk serbuk, bau khas tepung, dan warna putih kekuningan. Kadar air tepung biji nangka dengan metode basah sebesar 8,4\% yang masih dalam batas toleransi persyaratan SNI 3751:2009 sebesar 14,5\%. Untuk kadar abu dengan metode basah sebesar 1,45\% tidak memenuhi persyaratan SNI 3751:2009 sebesar 0,70\%. Untuk uji ALT dengan metode basah diperoleh $19 \times 10^{1} \mathrm{koloni} / \mathrm{gram}$. Uji AKK dengan metode basah diperoleh $34 \times 10^{3} \mathrm{koloni} /$ gram yang masih dalam batas toleransi persyaratan SNI 3751:2009 untuk ALT sebesar $1 \times 10^{6}$ dan AKK sebesar $1 \times 10^{4}$.

\section{DAFTAR PUSTAKA}

Andarwulan, dkk. 2011. AnalisisPangan.Jakarta : Dian rakyat

Atma,Y. 2016. Angka Lempeng Total (ALT), Angka Paling Mungkin (APM) dan Total KapangKhamir Sebagai Metode Analisis Sederhan Untuk Menentukan Standar Mikrobiologi Pangan Olahan Posdaya. JurnalTeknologi Vol. 8 No. 2

Husna, A, dkk.2017. Pembuatan Tepung Dari Biji Kakao (Theobroma cacao L) dan Uji Kualitasnya. JurnalAkdemika Kimia, 6 (02)

Irawati, Ap. 2007. I BAB I Pendahuluan A. Latar Belakang Tanaman Nangka. (online) (http/eprintes.ums,ac.id/10922/2/Bab - 1.pdf) diakses 26 Februari 2019

J.Akad.Kim. 2017.PembuatanTepung Dari BijiKakao (Theobroma cacao L) danUjiKualitasnya. Universitas of Tadulako.Palu.

Laeliocattleya, R.A dan Jessica Wijaya. 2018. Pengaruh Variasi Komposisi GristGandum (Triticumasetivum L.) Terhadap Kadar Air dan Kadar Abu Tepung Terigu. JurnalIlmuPangandanHasilPertanian, 2 (1)

Purnomo danWinarti. 2006. Dalam: Hartika, W. 2009. Kajian Sifatdan Kimia TepungBijiNangka (Artocarpus heterophyllus Lamk) danAplikasinyadalamPembuatan Roti Manis. Skripsi Tidak Diterbitkan. Padang, Unuversitas Andalas.

Standar Nasional Indonesia, 2009.TepungBerasNomor 3549:2009. Jakarta: Badan Standarisasi Nasional Winarno, F.G. 2008. Kimia PangandanGizi. Jakarta: PT Gramedia Pustaka Umum. 